\title{
S1PR3 wt Allele
}

National Cancer Institute

\section{Source}

National Cancer Institute. S1PR3 wt Allele. NCI Thesaurus. Code C104777.

Human S1PR3 wild-type allele is located within 9q22.1-q22.2 and is approximately $14 \mathrm{~kb}$ in length. This allele, which encodes sphing osine 1-phosphate receptor 3 protein, may be involved in regulating angiogenesis and vascular endothelial cell function. 